\title{
Mayer-Rokitansky-Kuster-Hauser syndrome and ovarian benign teratoma: a case report
}

\section{Cassou R. Adjoby*, Soh V. Koffi, Denis Effoh, Eleonore Gbary-Lagaud, Christian H. Alla, Okoin P. J. Loba, Yao R. Abauleth}

Department of Gynecology and Obstetrics of The Teaching Hospital of Angré/Abidjan, Côte d'Ivoire

Received: 04 December 2019

Accepted: 02 January 2020

\section{*Correspondence: \\ Dr. Cassou R. Adjoby, \\ E-mail: r.adjoby@yahoo.fr}

Copyright: () the author(s), publisher and licensee Medip Academy. This is an open-access article distributed under the terms of the Creative Commons Attribution Non-Commercial License, which permits unrestricted non-commercial use, distribution, and reproduction in any medium, provided the original work is properly cited.

\begin{abstract}
Mayer-Rokitansky-Kuster-Hauser syndrome (MRKH) is an unknown congenital etiology disorder characterized by agenesia or hypoplasia of the Müller ductal system, including the upper vagina, uterus and fallopian tubes. The occurrence of an associated ovarian tumor is rare, with fewer than 20 cases reported to date according to the literature. We report the case of a 14-year-old girl, virgin, who had not yet seen her menarche, complaining of an abdominopelvic mass associated with pain. The ultrasound performed revealed a large left ovarian tumor and an absence of uterus. The indication of a laparotomy confirmed the ovarian mass and a complete absence of uterus associated with vaginal hypoplasia. The contralateral ovary was present, and of normal appearance. The pathological examination was in favor of a mature benign multi-tissular teratoma. This is the first case described in our service. The mode of transmission of this entity appears to be autosomal dominant with low penetrance and variable expressivity, suggesting that the incidence of this syndrome is likely underestimated. With the development of techniques of medical assistance to procreation, maternity remains possible, particularly through gestational surrogacy.
\end{abstract}

Keywords: Agenesia, Mayer-Rokitansky-Kuster-Hauser, Ovarian tumor, Uterine hypoplasia

\section{INTRODUCTION}

Mayer-Rokitansky-Kuster-Hauser syndrome (MRKH) is a rare abnormality characterized by congenital aplasia of the uterus and vagina in women with normal development of secondary sex characteristics and a karyotype $44 \mathrm{XX} .{ }^{1}$ It is a rare disease, which is a common cause of primary amenorrhoea. ${ }^{2}$ The etiological basis of the syndrome has not yet been defined. Most cases are sporadic, although family groupings were reported, suggesting an alleged genetic origin of the syndrome. However, data on genetic and genomic alterations identified in patients with MRKHS, as well as the hereditary patterns observed, are consistent with a polygenic disorder. ${ }^{3}$ In addition, association with other malformations involving the kidneys, skeleton and ears is common. ${ }^{4,5}$ The occurrence of a gynecological tumor was reported in only a few cases of MRKHS syndromes. ${ }^{6}$ However, data on the association of a benign ovarian tumor are still limited. Authors report here a case of MRKH syndrome discovered during a laparotomy for a large ovarian tumor.

\section{CASE REPORT}

This is DH, a 14-year-old patient, who consulted at Angré teaching hospital in Abidjan for a large abdominalpelvic mass associated with pelvic pain. The evolution was progressive over a period of about 6 months. She had no other associated sign apart from the effects related to compression. The interrogation found an absence of menarche. She never had sexual intercourse. The physical 
examination performed in the patient noted a good general condition, a normal morphotype, the hemodynamic constants were normal. The examination of the abdomen revealed a large, firm, regular, painless mass, ranging from the pelvic region to the xiphoid appendage (Figure 1). Examination of the vulva did not objectify any abnormality; the hymen was intact. In addition, the pleuro-pulmonary and cardiovascular examinations were without particularity.

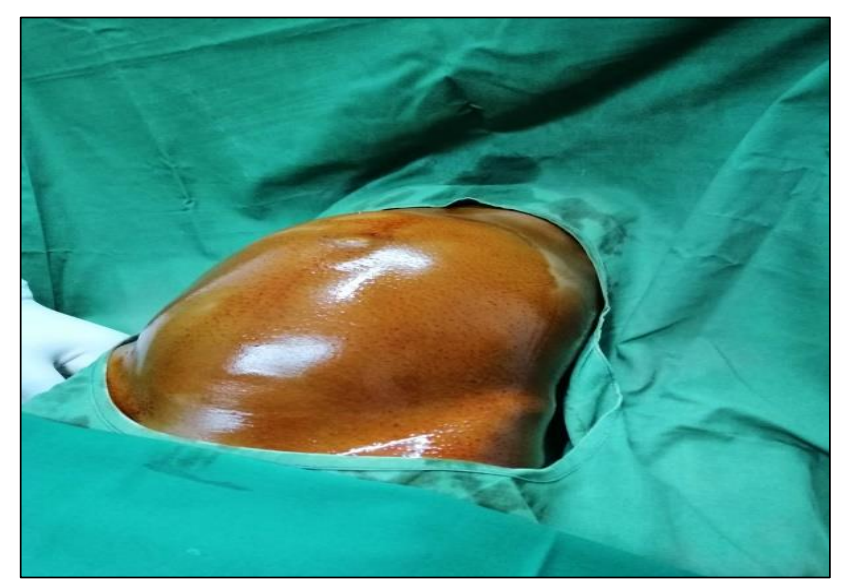

Figure 1: Abdominal-pelvic mass.

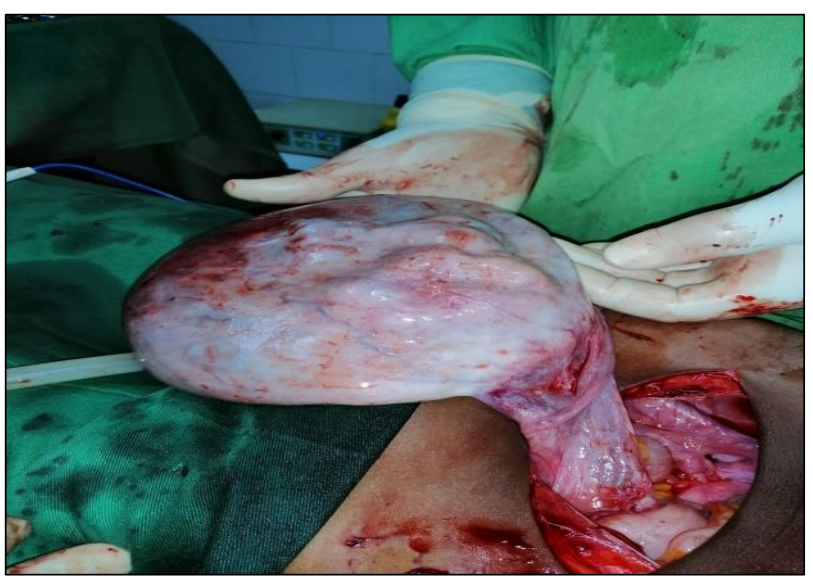

Figure 2: Pre-operative left ovarian tumor.

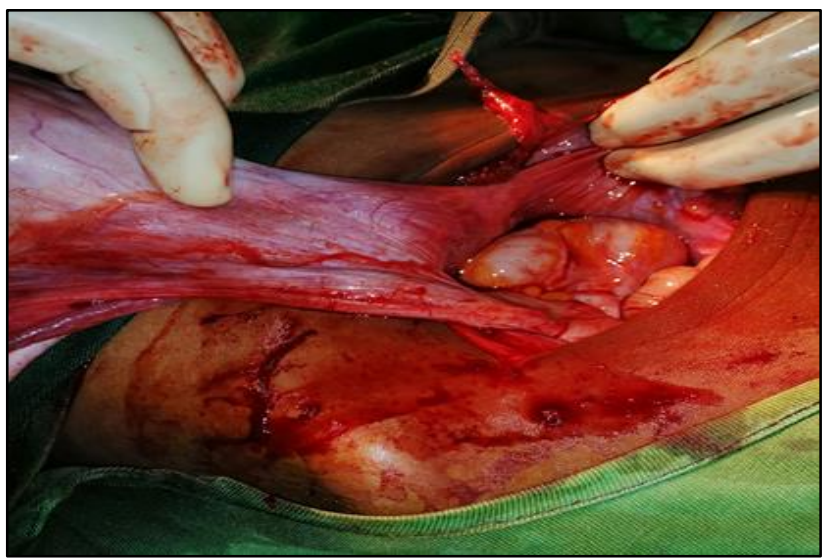

Figure 3: Absence of uterus.

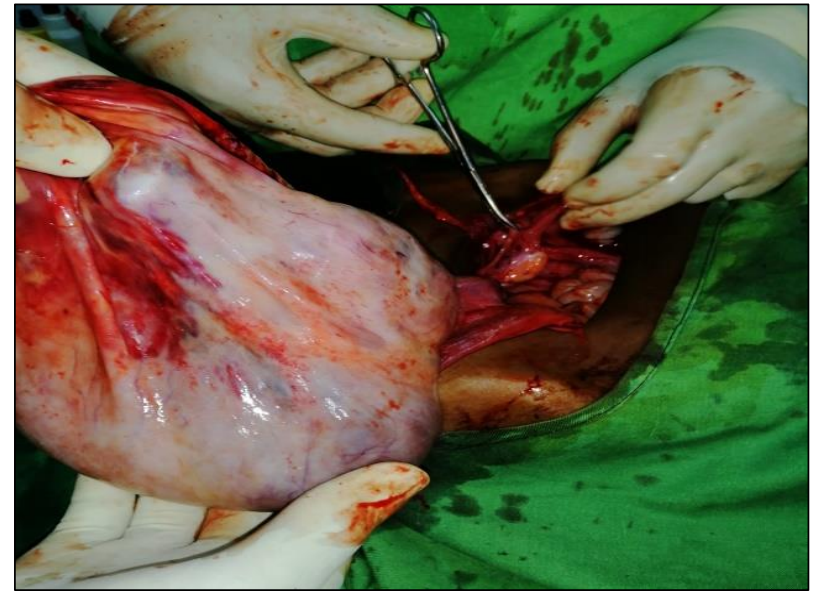

Figure 4: Healthy contralateral appendage.

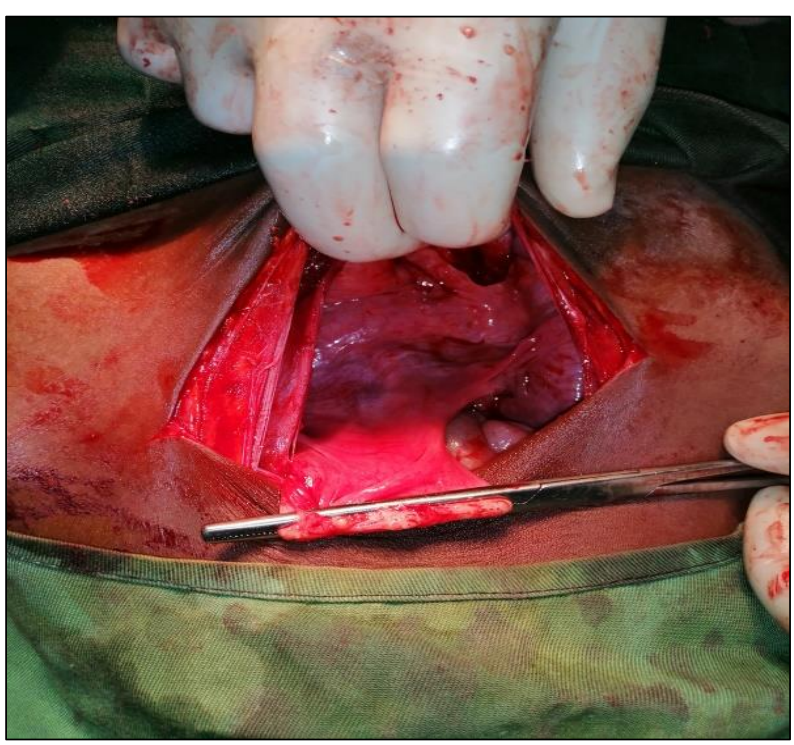

Figure 5: Adnexectomy.

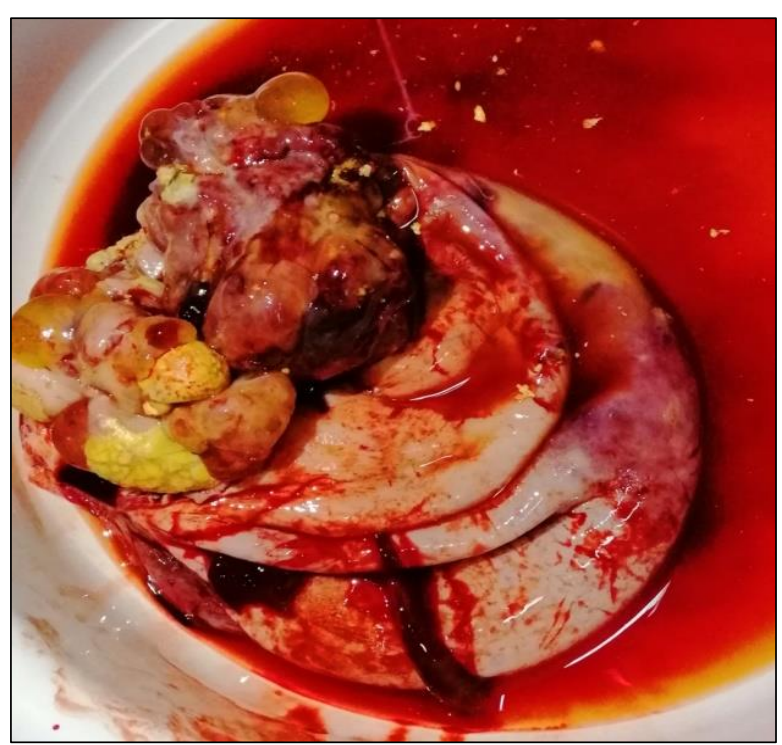

Figure 6: Mixed ovarian tumor. 
Table 1: Observations of MRKH associated with ovarian tumors.

\begin{tabular}{|c|c|c|c|c|c|c|c|}
\hline Articles & Country & $\begin{array}{l}\text { MRKHS } \\
\text { type }\end{array}$ & $\begin{array}{l}\text { Ovarian } \\
\text { tumor age } \\
\text { at onset }\end{array}$ & $\begin{array}{l}\text { Ovarian } \\
\text { tumor } \\
\text { histology }\end{array}$ & $\begin{array}{l}\text { Ovarian tumor } \\
\text { type }\end{array}$ & $\begin{array}{l}\text { Ovarian } \\
\text { tumor } \\
\text { grade }\end{array}$ & $\begin{array}{l}\text { Ovarian } \\
\text { tumor stage } \\
\text { (FIGO) }\end{array}$ \\
\hline Takeuchi et al & Japan & NA & 8 & Germ cell & Yolk sac tumor & $\mathrm{Na}$ & I \\
\hline Mishina et al & Moldova & NA & 35 & Germ cell & Dysgerminoma & $\mathrm{Na}$ & I \\
\hline Kavallaris et al & Germany & II & 48 & Epithelial & $\begin{array}{l}\text { Mixed epithelial } \\
\text { carcinoma }\end{array}$ & III & III \\
\hline Bae et al & Korea & II & 31 & Epithelial & Serous papillary & NA & III \\
\hline Ko et al & Korea & II & 37 & Epithelial & $\begin{array}{l}\text { Serous } \\
\text { carcinoma }\end{array}$ & III & III \\
\hline Nusrath et al & India & II & 65 & Epithelial & $\begin{array}{l}\text { Endometrioid } \\
\text { carcinoma }\end{array}$ & $\mathrm{Na}$ & I \\
\hline Juusela et al & $\begin{array}{l}\text { United } \\
\text { States }\end{array}$ & I & 72 & $\begin{array}{l}\text { Sex-cord } \\
\text { stromal }\end{array}$ & $\begin{array}{l}\text { Bilat. Sex-cord } \\
\text { stromal tumor }\end{array}$ & $\mathrm{Na}$ & I \\
\hline \multirow{2}{*}{ Huepenbecker et al } & \multirow{2}{*}{$\begin{array}{l}\text { United } \\
\text { States }\end{array}$} & NA & 64 & Epithelial & $\begin{array}{l}\text { Serous } \\
\text { carcinoma }\end{array}$ & III & III \\
\hline & & NA & 63 & Epithelial & $\begin{array}{l}\text { Serous tubal } \\
\text { carcinoma }\end{array}$ & III & III \\
\hline Villa $R$ et al & Italy & I & 33 & Epithelial & $\begin{array}{l}\text { Bilat. Serous } \\
\text { carcinoma }\end{array}$ & I & II \\
\hline
\end{tabular}

In front of this voluminous abdomino-pelvic mass, an ultrasound was made, and concluded to a voluminous left ovarian tumor $(210 \mathrm{~mm})$ of long axis. The requested tumor markers (ACE, CA125, CA19.9, alpha-fetoprotein) were normal, as was the conventional preoperative assessment. The intervention was planned, and intraoperatively, it was a large mixed tumor (fluid and solid) about $25 \mathrm{~cm}$ in diameter, developed at the expense of the left ovary (Figure 2). There was a complete absence of uterus (Figure 3). The ovary and contralateral tube (right appendage), were macroscopically healthy (Figure 4). Aspiration of the contents of the tumor allowed to collect 2 liters of citrine liquid. A left total adnexectomy was performed (Figure 5). The tumor after opening, was a mixed ovarian tumor (Figure 6). The operative follow-up was simple, the exit was decided at D4 postoperative with a post-operative appointment at D15. The histology performed revealed a benign pluritissular mature teratoma. A complementary radiological study of the urinary shaft did not reveal any associated malformations.

\section{DISCUSSION}

\section{Epidemiology}

The prevalence of MRKH syndrome is estimated at 1 per 4,000 female live births in the Caucasians. In addition, the etiology of MRKH syndrome remains unknown. ${ }^{2,7}$ The majority of cases appear to be sporadic, however, reports of familial cases of MRKH syndrome suggest a genetic component. ${ }^{8}$ In our patient, we found no family history of this pathology whose prevalence is unknown, and which remains a mystery in our country.

\section{Diagnosis}

The MRKH syndrome is a devastating diagnosis for a young woman to receive, which has considerable medical, psychological, social and reproductive implications. The diagnosis is often made in adolescence in the context of primary amenorrhea with normal puberty. ${ }^{4}$ In our observation, the diagnosis was fortuitous following a laparotomy for a large ovarian tumor in a 14year-old girl with no particular history. This condition, often suspected in the face of primary amenorrhoea, is usually confirmed radiologically (ultrasound or MRI) or by laparoscopy in patients for whom hormonal examinations and karyotype are normal. ${ }^{9}$ The MRKH syndrome was subdivided into 2 types: type I, with malformations of the Müller's canal which are in the form of a superficial vaginal dimple with uterine cervix, uterus and upper vagina absent and is not associated with other abnormalities. Type II with Müller's canal agenesia similar to type I and various degrees of associated congenital renal malformations (renal agenesia and horseshoe kidney), skeletal abnormalities (scoliosis, spina bifida) and in rare cases of unilateral hearing defects, cardiac and extremities abnormalities. ${ }^{10}$ In our case, the patient was only 14 years old, and had not yet seen her menarche, which was not a concern for parents. MRKH syndrome was discovered during a laparotomy for ovarian tumor. The clinical and paraclinical investigations carried out did not reveal any other malformations. It was a type I. In the most recent publications on MRKH syndrome, we could find cases reported on leiomyoma, adenomyosis, but ovarian tumor is rare in MRKH syndrome and difficult to diagnose if it is not bulky. ${ }^{11-14}$ The incidence of the combination of 
MRKH with ovarian tumors was not reported. However, a review of the literature demonstrated nearly a dozen reported cases of MRKH syndrome associated with ovarian tumors (Table 1). Benign tumors were predominant in most studies. This is the case in our observation, or it was a left ovarian benign multi tissular teratoma which is a benign tumor often called ovarian dermoid cyst.

\section{Treatment}

Laparoscopy is the gold standard for the diagnosis and management of benign ovarian tumors. In the literature, in five cases described, associating an ovarian tumor with MRKH syndrome, management was performed under laparoscopy, which confirms the interest of this approach. ${ }^{15}$ In addition, conventional surgery by laparotomy is possible, especially in case of large solid or mixed tumor as was the case in our observation. In addition, the patient's care remains holistic, taking into account the psychosocial aspects, vaginoplasty to improve sexual practice and the possibility of medical assistance, the cost of which is prohibitive in our country. ${ }^{4,16,17}$

\section{CONCLUSION}

MRKHS syndrome is a rare condition. The association with a voluminous ovarian tumor is even rarer, if not exceptional. The available data and knowledge on the etiopathogenic factors being still limited, it is impossible to define a supposed correlation between these two affections. The collection of new data and the publication of possible new cases could lead to a better knowledge of this association. With the rise of assisted reproduction techniques (ART), maternity remains possible.

Funding: No funding sources

Conflict of interest: None declared

Ethical approval: Not required

\section{REFERENCES}

1. Morcel K, Guerrier D, Watrin T, Pellerin I, Levêque J. Mayer-Rokitansky-Kuster-Hauser Syndrome (MRKH): clinical and genetic. Gyn Obstet Biol Day Rep. 2008;37:539-46.

2. Drummond JB, Rezende CF, Peixoto FC, Carvalho JS, Reis FM, De Marco L. Molecular analysis of the Bcatenin gene in patients with Mayer - RokitanskyKuster-Hauser syndrome. J Assist Reprod Genet. 2008;25:5-54.

3. Fontana L, Gentilin B, Fedele L, Gervasini C, Miozzo M. Genetics of Mayer - Rokitansky - Küster - Hauser (MRKH) syndrome. Clin Genet. 2017;91:233-46.
4. Khen-Dunlop N, Lortat-Jacob S, Thibaud E, ClémentZiza M, Lyonnet S, Nihoul-Fekete C. Rokitansky: Clinical experience and results of sigmoid vaginoplasty in 23 young girls. J Urol. 2007;177:1107-11.

5. Burel A, Mouchel T, Odent S, Tiker F, Knebelmann B, Pellerin I, et al. Role of the HOXA7 to HOXA13 and PBX1 genes in various forms of MRKH syndrome (congenital absence of the uterus and vagina) J Negat Results Biomed. 2006;5:4.

6. Huepenbecker SP, Divine L, Chu CS, Mutch DG. Two sisters with Mayer-Rokitansky-Küster-Hauser syndrome and serous adenocarcinoma of the ovary. Gynecol Oncol Rep. 2017;22:13-5.

7. Herlin M, Bjørn AMB, Rasmussen M. Prevalence and characteristics of Mayer - Rokitansky - Küster - Hauser syndrome: a national registry-based study. Hum Reprod. 2016;31:2384-90.

8. Herlin M, Højland AT, Petersen MB. Family presence of Mayer-Rokitansky-Küster-Hauser syndrome: about a case and review of the literature. Am J Med Genet A. 2014;164A: 2276-286.

9. Gupta PN, Ansari MS. Mayer-Rokitansky-KusterHauser syndrome: a review. Indian J Urol. 2002;18:116.

10. Bombard DS, Mousa SA. Mayer-Rokitansky-KusterHauser syndrome: Complications, diagnosis and possible treatment options: a review. Gynecol Endocrinol. 2014;30(9):618-23.

11. Girma W, Woldeyes W. Leiomyoma arising from mullerian remnant, mimicking ovarian tumor in a woman with MRKH syndrome and unilateral renal agenesis. Ethiopian J Health Sci. 2015;25(4):381-4.

12. Dong LJH, Dai Y. A rare case of MRKH with adenomyosis and literature review. Chin J Pract Gynecol Obstet. 2009;25:936-7.

13. Colovic R, Grubor N, Colovic N. Giant liver abscess due to almost asymptomatic common bile duct stone. Srpski Arhiv za Celokupno Lekarstvo. 2002;130(1112):406-8.

14. Takeuchi M, Matsuzaki K, Kusaka M. Ovarian cystadenofibromas: characteristic magnetic resonance findings with pathologic correlation. J Computer Assisted Tomo. 2003;27(6):871-3.

15. Yali M, Jirui W, Liwei H, Jiang W, Zhiwei $Z$. Diagnosis and management of ovarian tumor in MayerRokitansky-Küster-Hauser syndrome (MRKH). List Biomed Res Intv J. 2018;2018:2369430.

16. Herlin M, Bay Bjorn AM, Jorgensen LK. Treatment of vaginal agenesis in Mayer-Rokitansky-Küster-Hauser syndrome in Denmark: a nationwide comparative study of anatomical outcome and complications. Fertil Steril. 2018;110:746-53.

17. Egbe TO, Kobenge FM, Metogo MJ, Nyemb JE, Mbu RE. A case of Mayer-Rokitansky-Kuster-Hauser syndrome in a low-resource tertiary hospital in Douala, Cameroon. Sage Open Med Case Repo. 2019;7:1-4.

Cite this article as: Adjoby CR, Koffi SV, Effoh D, Gbary-Lagaud E, Alla CH, Loba OPJ, et al. MayerRokitansky-Kuster-Hauser syndrome and ovarian benign teratoma: a case report. Int J Reprod Contracept Obstet Gynecol 2020;9:815-8. 